\title{
Analisis Pengaruh Layanan Digital Perbankan Syariah terhadap Literasi Keuangan Syariah Generasi Milenial
}

\author{
Rozaq M. Yasin ${ }^{1}$, Nurzahroh Lailyah ${ }^{2}$, Mochamad Edris \\ Universitas Muria Kudus \\ Email : rozaq.yasin@umk.ac.id ${ }^{1,}$ nurzahroh.lailyah@umk.ac.id ${ }^{2}$, \\ mochamad.edris@umk.ac.id ${ }^{3}$
}

Abstract

Keywords

: Good financial literacy, especially in the digital era now is important to be understood by millennials. The digitization of Islamic which is able to provide more efficient, safer, faster financial products and the risk of losing money is less well understood by this generation. Islamic digital banking services like mobile banking and internet banking, which describe the virtual process to support all services, are expected to be able to significantly increase the level of Islamic banking literacy and have a positive impact on business growth in general. This study used a quantitative descriptive research design. The sampling method used purposive sampling method. Data was obtained by using questionnaire which was distributed to 100 millennial respondents who used m-banking or i-banking in Kudus. The answers to the questionnaire were measured using a rating scale, then data was analysed by multiple linear regression. The results showed that $m$-banking and $i$-banking had a significant and positive effect to the literacy of millennials about Islamic banks in Kudus. It was proven by a significance value of 0.000 ( $p<0.05$ ). The $R$-square value is 0.775 , which means the contribution of the influence provided by $\mathrm{m}$ banking and i-banking services to millennials Islamic financial literacy in Kudus is $77.5 \%$, while the remaining $22.5 \%$ is influenced by other variables.

Abstrak : Literasi keuangan yang baik khususnya dalam ranah digital saat ini menjadi penting dipahami oleh generasi milenial. Digitalisasi perbankan syariah mampu menyediakan produk-produk keuangan yang lebih efisien, aman, cepat, dan resiko kehilangan uang lebih kecil masih belum dipahami dengan baik oleh generasi ini. Layanan digital perbankan syariah dalam hal ini mobile banking dan internet banking yang menggambarkan proses virtual penunjang seluruh layanan diharapkan mampu secara nyata menaikkan tingkat literasi perbankan syariah dan berdampak positif pada pertumbuhan bisnis secara umum. Penelitian ini menggunakan desain penelitian deskriptif kuantitatif. Teknik pengambilan sampel menggunakan purposive sampling. Data diperoleh menggunakan angket yang disebar kepada 100 responden generasi milenial di Kudus yang menggunakan $\mathrm{m}$ banking atau $i$-banking. Jawaban angket diukur menggunakan rating scale, kemudian analisis data menggunakan regresi linier berganda. Hasil penelitian menunjukkan bahwa m-banking dan i-banking berpengaruh signifikan dan positif terhadap literasi bank syariah generasi milenial di Kudus. Hal ini dibuktikan dengan nilai signifikansi sebesar $0,000(\mathrm{p}<0,05)$. Nilai $R$-square sebesar 0,775 yang berarti kontribusi pengaruh yang diberikan oleh layanan $m$-banking dan $i$-banking terhadap literasi keuangan syariah generasi milenial di Kudus sebesar 77,5\%, sedangkan sisanya sebesar 22,5\% dipengaruhi oleh variabel lain.

Kata Kunci : $m$-banking, $i$-banking, literasi, generasi milenial. 


\section{A. Pendahuluan}

Survei nasional pertama kali mengenai literasi dan inklusi keuangan syariah tahun 2016 menunjukkan indeks literasi keuangan syariah berada pada posisi $8,1 \%$. Artinya dari 100 orang di Indonesia, hanya 8 orang yang memiliki literasi keuangan yang baik. Angka tersebut masih jauh dibawah literasi keuangan nasional yang pada survei terakhir tahun 2019 menunjukkan angka sebesar 38,03\%. Bahkan dari 34 provinsi di Indonesia yang memiliki literasi baik tentang perbankan hanya sebesar 36,12\%. Rata-rata indeks literasi keuangan yang rendah tersebut menunjukkan bahwa masyarakat menggunakan produk dan layanan jasa keuangan syariah maupun konvensional tanpa diimbangi pengetahuan mengenai produk dan layanan yang digunakannya ${ }^{1}$. Rendahnya pemahaman maupun akses ini dapat diatasi dengan upaya mengombinasikan layanan dan produk keuangan dengan teknologi terkini ${ }^{2}$.

Saat ini perkembangan teknologi yang sangat pesat mengarahkan perbankan untuk lebih meningkatkan layanan dengan membentuk perbankan digital ${ }^{3}$. Kondisi tersebut membawa dampak pada peningkatan transaksi layanan keuangan digital seperti mobile payment (mpayment), mobile banking (m-banking), internet banking, dan electronic money (e-money) yang disediakan oleh perbankan. Selama masa pandemi Covid-19, menurut Heru Kristiyana Kepala Eksekutif Pengawas Perbankan Otoritas Jasa Keuangan (OJK) mencatat tren penggunaan transaksi digital mengalami peningkatan yang signifikan sebesar $320 \%$ pada maret 2020 dan naik $480 \%$ pada April $2020^{4}$. Peningkatan transaksi digital tersebut harapannya tentu diikuti dengan literasi perbankan syariah yang lebih baik.

Literasi keuangan yang baik khususnya dalam ranah digital saat ini menjadi penting mengingat Indonesia memiliki potensi ekonomi digital terbesar di Asia Tenggara ${ }^{5}$. Digitalisasi perbankan merupakan suatu sistem yang berhubungan dengan teknologi dalam ranah perbankan yang akan memudahkan nasabah untuk menikmati layanan perbankan ${ }^{6}$. Dengan melakukan inovasi digital perbankan mampu menaikkan kinerja kepuasan nasabah perbankan itu sendiri ${ }^{7}$. Apalagi dengan adanya digitalisasi perbankan membawa peluang lebih besar bagi bank untuk menjangkau masyarakat yang tinggal jauh dari kantor bank untuk mengakses layanan yang disediakan ${ }^{8}$.

Bank Indonesia dan Otoritas Jasa Keuangan telah mengeluarkan sejumlah regulasi mengenai layanan keuangan digital untuk meningkatkan literasi dan inklusi keuangan di Indonesia. Tantangan transformasi pemanfaatan teknologi digital selain menyediakan layanan daring dan mobile banking, juga harus bisa mempermudah dan memberikan kenyamanan bagi pengguna dalam mengakses layanan perbankan syariah ${ }^{9}$. Sehingga layanan tersebut mampu

${ }^{1}$ OJK, Survei Nasional Literasi Dan Inklusi Keuangan 2019, Survey Report, 2019, www.ojk.go.id.

${ }^{2}$ Irfan Nurfalah and Aam Slamet Rusydiana, "Digitalisasi Keuangan Syariah Menuju Keuangan Inklusif: Kerangka Maqashid Syariah," Ekspansi: Jurnal Ekonomi, Keuangan, Perbankan dan Akuntansi 11, no. 1 (2019): 55.

${ }^{3}$ Vera Vebiana, "Perbankan Digital , Pengalaman Pelanggan , Dan Kinerja Keuangan Bank Syariah," 9th Industrial Research Workshop and National Seminar (2018): 747-751, file:///C:/Users/win7/Downloads/1145Article Text-2220-1-10-20180830 (1).pdf. diakses tanggal 25 Desember 2020

4 Yuni Astutik, "Ada 2 Masalah Di Balik Literasi Keuangan Digital RI," last modified 2020, https://www.cnbcindonesia.com/news/20200824170208-4-181599/ada-2-masalah-di-balik-literasi-keuangandigital-ri. diakses tanggal 25 November 2020

5 Churry, "Literasi Keuangan Digital Meningkat Di Tengah Pandemi," last modified 2020, https://www.itworks.id/33720/literasi-keuangan-digital-meningkat-di-tengah-pandemi.html. diakses pada 25 Januari 2021 diakses tanggal 25 November 2020

${ }^{6}$ Siti Bunga Fatimah and Achsania Hendratmi, "Digitalisasi Pada Bank Mandiri Syariah Di Tengah Persaingan Dan Perubahan Teknologi," Jurnal Ekonomi Syariah Teori dan Terapan 7, no. 4 (2020): 795.

${ }^{7}$ Lilis Susilawaty and Nicola Nicola, "Pengaruh Layanan Perbankan Digital Pada Kepuasan Nasabah Perbankan,” Jurnal Manajemen Maranatha 19, no. 2 (2020): 179-190.

${ }^{8}$ Chenny Seftarita and Uliya Azra, "Analisis Peluang Penggunaan Layanan Keuangan Digital (Lkd) Pada Masyarakat Kabupaten Aceh Besar Provinsi Aceh," Jurnal Ekombis III, no. 1 (2017): 1-16, http://180.250.41.45/ekombis/article/view/385.

${ }^{9}$ S Sumadi, "Menakar Dampak Fenomena Pandemi Covid-19 Terhadap Perbankan Syariah," Jurnal Hukum Ekonomi Syariah, no. 1 (2020): 145. 
mendukung pengembangan literasi keuangan inklusif, serta mendukung penyaluran dana dari pemerintah secara lebih efektif dan tepat sasaran.

Literasi keuangan secara sederhana bisa diartikan sebagai melek keuangan. Menurut buku pedoman Strategi Nasional Literasi Keuangan Indonesia, yang dimaksud dengan literasi keuangan adalah rangkaian proses atau aktivas untuk meningkatkan pengetahuan (knowledge), keyakinan (confidence) dan keterampilan (skill) yang mempengaruhi sikap dan perilaku untuk meningkatkan kualitas pengambilan keputusan dan pengelolaan keuangan dalam rangka mencapai kesejahteraan ${ }^{10}$.

Meskipun tujuan program pembangunan literasi keuangan syariah adalah untuk memperluas dan meningkatkan pengetahuan, pemahaman dan peran serta masyarakat dalam penggunaan produk dan jasa keuangan syariah. Namun belum tentu masyarakat yang memiliki tingkat literasi keuangan syariah yang baik akan mau menggunakan produk dan layanan keuangan syariah. Atau sebaliknya, masyarakat yang menggunakan produk dan layanan keuangan syariah memiliki literasi keuangan yang baik.

Pengetahuan literasi keuangan yang baik diperlukan untuk mengubah perilaku masyarakat dalam mengelola keuangan secara cerdas dan bijak dalam memilih investasi yang halal dan menguntungkan, mampu mencegah masyarakat mengikuti investasi bodong yang kerap muncul di tengah masyarakat. Literasi keuangan seseorang dipengaruhi oleh banyak faktor. OJK sendiri mengemukakan beberapa faktor yang mempengaruhi literasi keuangan yaitu: 1) jenis kelamin; 2) tingkat pendidikan; 3) tingkat pendapatan ${ }^{11}$.

Selain itu karakteristik pribadi nasabah mungkin mempengaruhi perilakunya terutama dalam menyikapi keberadaan layanan digital perbankan syariah. Generasi yang lahir antara tahun 1980 - 2000 atau biasa disebut generasi milenial yang juga tumbuh seiring perkembangan teknologi internet dan gadget memiliki pola perilaku tersendiri. Karakter yang dimiliki generasi ini jauh berbeda dengan generasi sebelumnya. Generasi milenial memiliki sifat yang tidak loyal, rasa ingin tahu yang tinggi, agresif dan penuh pertimbangan dalam menentukan perilakunya, tak terkecuali dalam menggunakan layanan digital yang disediakan perbankan syariah.

Layanan keuangan digital menjadi pilihan logis kekinian yang dibutuhkan untuk meningkatkan efisiensi operasional dan juga efisiensi biaya ${ }^{12}$ terutama bagi generasi milenial saat ini. Efektifitas dan efisiensi layanan digital perbankan dirasa memberikan manfaat yang banyak dan membantu generasi milenial dalam memenuhi kebutuhan transaksi keuangannya seperti berbelanja online, pembayaran tagihan, pembelian pulsa, dan transfer antar bank ${ }^{13}$. Dengan adanya digitalisasi layanan mampu mengatasi kesenjangan layanan antar bank dengan masyarakat menjadi lebih dekat, hemat, efisien, cepat, dan murah ${ }^{14}$ yang sangat disukai oleh generasi milenial saat ini.

Umumnya, generasi milenial aktif mencari informasi terkait produk yang akan digunakan. Meskipun begitu, hasil penelitian Margaretha dan Pambudhi menyimpulkan bahwa tingkat literasi keuangan mahasiswa S-1 fakultas Ekonomi Universitas Trisakti yang dianggap mewakili perilaku generasi milenial berada dalam kategori rendah yaitu $48,91 \%{ }^{15}$. Kondisi tersebut cukup memprihatikan karena literasi keuangan yang tinggi penting dimiliki

${ }^{10}$ Otoritas Jasa Keuangan, Strategi Nasional Literasi Keuangan Indonesia, Otoritas Jasa Keuangan, 2017.

${ }^{11}$ OJK, Survei Nasional Literasi Dan Inklusi Keuangan 2019.

${ }^{12}$ Dikdik Herdiana, "Digital Financial Services (Layanan Keuangan Digital): Peluang Dan Kemungkinan Penerapannya Di Program KOTAKU," Advisory Consultant National Slum Upgrading Program (2014): 1-20.

${ }^{13}$ Hanny Amalia, N Eva Fauziah, and Ifa Hanifia, "Effectiveness and Efficiency of Digital Financial Services System in Employee of DPU Daarut Tauhiid," in Posiding Keuangan Dan Perbankan Syariah, 2017, $442-446$.

${ }^{14}$ Abdus Salam Dz., "Inklusi Keuangan Perbankan Syariah Berbasis Digital-Banking: Optimalisasi Dan Tantangan,” Al-Amwal : Jurnal Ekonomi dan Perbankan Syari'ah 10, no. 1 (2018): 63.

${ }^{15}$ Farah Margaretha and Reza Arief Pambudhi, "Tingkat Literasi Keuangan Pada Mahasiswa S-1 Fakultas Ekonomi," JMK 17, no. 1 (2015): 76-85. 
agar seseorang mampu membuat perencanaan keuangan yang baik ${ }^{16}$, lebih bijaksana dan pandai dalam mengelola asset yang dimilikinya ${ }^{17}$. Artinya seseorang dengan tingkat literasi finansial rendah lebih banyak memilih keputusan keuangan yang salah dibandingkan dengan mahasiswa yang memiliki tingkat literasi finansial yang lebih tinggi ${ }^{18}$. Literasi keuangan juga tidak selalu dipengaruhi oleh gender, usia, kemampuan akademis dan pengalaman kerja ${ }^{19}$.

Dari beberapa penelitian yang telah dilakukan, diketahui bahwa belum adanya penelitian yang berkaitan dengan pengaruh layanan digital bank syariah terhadap literasi keuangan syariah generasi milenial di Kudus. Sehingga menarik untuk diteliti mengenai hal tersebut mengingat konteks budaya, nilai, dan demografi masyarakat Kudus yang mungkin berbeda dengan kota lain terutama dalam menyikapi program layanan digital perbankan tersebut. Kajian tersebut perlu dilakukan agar layanan digital perbankan syariah dalam hal ini mobile banking dan internet banking yang menggambarkan proses virtual penunjang seluruh layanan mampu secara nyata menaikkan tingkat literasi perbankan syariah dan berdampak positif pada pertumbuhan bisnis secara umum ${ }^{20}$.

\section{B. Metode Penelitian}

Metode penelitian yang digunakan dalam penelitian ini adalah metode analisis kuantitatif, yaitu metode penelitian yang berlandaskan pada filsafat positivism, digunakan untuk meneliti pada populasi atau sampel tertentu, pengumpulan data menggunakan instrumen penelitian, analisis data bersifat kuantitatif/statistik, dengan tujuan untuk menguji hipotesis ${ }^{21}$. Desain penelitian ini adalah penelitian lapangan (field research), dimana data dan informasi dari penelitian diperoleh dari kegiatan lapangan. Desain penelitian menjadi model konstelasi penelitian untuk pengukuran pengaruh variabel bebas layanan digital bank syariah terhadap variabel terikat literasi keuangan syariah pada generasi milenial di Kudus.

Definisi operasional variabel independen yang digunakan dalam penelitian ini yaitu layanan digital bank syariah yang di proksikan dari fasilitas mobile-banking (m-banking) dan internet banking (i-banking) ${ }^{22}$. Sedangkan definisi variabel dependen penelitian ini adalah literasi keuangan syariah generasi milenial di Kudus yang diukur dengan 1) pemahaman keuangan; 2) kompetensi keuangan; 3) sadar akan resiko; 4) tanggung jawab keuangan ${ }^{23}$.

Populasi yang menjadi obyek dalam penelitian ini adalah seluruh generasi milenial yang ada di Kudus. Penentuan sampel penelitian menggunakan metode purposive sampling berdasarkan kriteria responden, yang mana responden memiliki fasilitas layanan digital bank syariah dan berdomisili di Kudus. Mengenai jumlah sampel yang diteliti, Nasir menyatakan bahwa tidak ada aturan yang tegas mengenai jumlah sampel yang dipersyaratkan untuk suatu penelitian dari populasi yang tersedia, serta tidak ada batasan yang jelas apa yang dimaksud sampel yang besar dan sampel yang kecil. Selain itu juga berpendapat bahwa hasil dari sebuah

${ }^{16}$ Soya Sobaya and Junaidi Safitri, "Pengaruh Literasi Keuangan Dan Lingkungan Sosial Terhadap Perencanaan Keuangan Pegawai Di Universitas Islam Indonesia,” ResearchGate, no. June (2016).

${ }^{17}$ Welly, Kardinal, and Ratna Juwita, "Analisis Pengaruh Literasi Keuangan Terhadap Keputusan Investasi Di STIE Multi Data Palembang,” Jurnal Ilmu Ekonomi (2018): 1-16.

${ }^{18}$ Ayu Krishna, Maya Sari, and Rofi Rofaida, Analisis Tingkat Literasi Keuangan Di Kalangan Mahasiswa Dan Faktor-Faktor Yang Mempengaruhinya, 2011, Literasi Keuangan, Faktor Demografis, Mahasiswa.

19 Nujmatul Laily, "Pengaruh Literasi Keuangan Terhadap Perilaku Mahasiswa Dalam Mengelola Keuangan," Journal of Accounting and Business Education 1, no. 4 (2016).

${ }^{20}$ H Tahliani, "Tantangan Perbankan Syariah Dalam Menghadapi Pandemi Covid-19," Madani Syari'ah 3, no. 2 (2020): 92-113, https://stai-binamadani.e-journal.id/Madanisyariah/article/view/205.

${ }^{21}$ Sugiyono, Metode Penelitian Kuantitatif (Bandung: CV. Alfabet, 2017).

${ }^{22}$ Layanan keuangan digital adalah kegiatan layanan jasa pembayaran dan keuangan yang menggunakan sarana teknologi digital seperti seluler atau web melalui pihak ketiga. Layanan keuangan digital pada penelitian ini mengacu pada pendapat Herdiana, "Digital Financial Services (Layanan Keuangan Digital): Peluang Dan Kemungkinan Penerapannya Di Program KOTAKU."

${ }^{23}$ Pengukuran literasi keuangan syariah pada penelitian ini menggunakan pendekatan hasil penelitian Sean Wise, "The Impact of Financial Literacy on New Venture Survival," International Journal of Business and Management 8, no. 23 (2013): 30-39. 
penelitian tidak tergantung pada besarnya jumlah sampel ${ }^{24}$. Berdasarkan pendapat diatas maka penyusun dalam penelitian ini mengambil sampel sejumlah 100 responden yang menggunakan fasilitas layanan digital Bank Syariah di Kudus.

Instrumen yang digunakan dalam penelitian ini berupa kuesioner yang disebarkan kepada generasi milenial di Kudus kemudian diukur dengan mengunakan rating scale. Penilaian rating scale dimulai dari paling buruk sampai dengan paling baik dengan skala $1-10$. Kuesioner disebar secara langsung maupun melalui daring (google form) menggunakan fasilitas media sosial yang ada. Kuesioner dalam penelitian ini bersifat tertutup dimana pertanyaan disajikan dalam bentuk yang terstruktur sehingga responden hanya diminta untuk memilih salah satu jawaban yang sesuai dengan karakteristik dirinya.

Penguji validitas instrument dilakukan dengan cara menghitung korelasi antara skor masing-masing butir pertanyaan dengan skor total menggunakan tehnik korelasi product moment person. Sedangkan untuk menguji realibilitas digunakan metode cronbach's alpha. Adapun teknik analisis data yang digunakan adalah melalui tahap: 1) Analisis deskriptif yaitu statistik yang digunakan untuk menganalisis data dengan cara mendiskripsikan atau menggambarkan data yang telah terkumpul sebagaimana adanya tanpa bermaksud membuat kesimpulan yang berlaku untuk umum; 2) Analisis verifikatif adalah analisis yang menggunakan data dari jawaban yang telah terkumpul dengan menggunakan perhitungan statistik.

Uji asumsi klasik yang digunakan meliputi 1) Uji Normalitas; 2) Uji Heteroskedastisitas; 3) Uji Autokorelasi; terakhir 4) Menggunakan Regresi Liniear Berganda untuk melihat pengaruh antar variabel penelitian. Formulasi model regresi liniear berganda adalah sebagai berikut:

$Y=u+b_{1} X_{1}+b_{2} X_{2}$

dimana:

$\mathrm{Y} \quad=$ Literasi Keuangan Syariah Generasi Milenial

$X_{1} \quad=$ Layanan Digital Bank Syariah menggunakan m-Banking

$X_{2} \quad=$ Layanan Digital Bank Syariah menggunakan i-Banking

a $\quad=$ Intersep (titik potong kurva terhadap sumbu Y)

$\mathrm{b} \quad=$ Kemiringan (slope) kurva linear

Hipotesis yang diajukan untuk jawaban sementara dalam penelitian ini adalah layanan keuangan digital $m$-banking dan $i$-banking berpengaruh positif terhadap literasi keuangan syariah generasi milenial.

\section{Hasil dan Pembahasan}

Penelitian ini menggunakan pendekatan deskriptif kuantitatif. Data penelitian diperoleh melalui kuesioner yang disebar ke 100 responden secara langsung maupun melalui google form menggunakan fasilitas whatsapp kepada generasi milenial kudus yang menggunakan fasilitas mobile-banking dan internet-banking dari bank syariah. Selain itu juga digunakan data pendukung dari buku, jurnal, laporan program dan lainnya. Karakteristik responden dalam penelitian ini meliputi jenis kelamin, status responden, usia, latar belakang pendidikan, pekerjaan, fasilitas digital banking yang digunakan.

Tabel 1 Statistik Deskriptif Responden

\begin{tabular}{|l|l|l|c|c|}
\hline No & Variabel & Keterangan & Jumlah Responden & Persentase \\
\hline \multirow{2}{*}{1.} & \multirow{2}{*}{ Jenis Kelamin } & Laki-laki & 48 & $48 \%$ \\
\cline { 2 - 4 } & & Perempuan & 52 & $52 \%$ \\
\hline 2. & Status Responden & Menikah & 27 & $27 \%$ \\
\hline
\end{tabular}

${ }^{24}$ Nasir, Metode Penelitian (Jakarta: Ghalia, 2003). h.240 


\begin{tabular}{|c|c|c|c|c|}
\hline & & Belum Menikah & 73 & $73 \%$ \\
\hline \multirow{2}{*}{3.} & \multirow{2}{*}{ Usia Responden } & $20-25$ & 84 & $84 \%$ \\
\hline & & $26-30$ & 16 & $16 \%$ \\
\hline \multirow{4}{*}{4.} & \multirow{4}{*}{ Pendidikan Responden } & SMA/K & 39 & $39 \%$ \\
\hline & & Diploma & 4 & $4 \%$ \\
\hline & & S-1/D4 & 53 & $53 \%$ \\
\hline & & Pascasarjana & 4 & $4 \%$ \\
\hline \multirow{2}{*}{5.} & \multirow{2}{*}{ Pekerjaan } & Mahasiswa & 36 & $36 \%$ \\
\hline & & Pekerja & 64 & $64 \%$ \\
\hline \multirow{4}{*}{6.} & \multirow{4}{*}{ Bank Syariah yang Digunakan } & Bank Mandiri Syariah & 27 & $27 \%$ \\
\hline & & BNI Syariah & 25 & $25 \%$ \\
\hline & & BRI Syariah & 25 & $25 \%$ \\
\hline & & Bank Syariah Lainnya & 23 & $23 \%$ \\
\hline \multirow{2}{*}{7.} & \multirow{2}{*}{ Fasilitas Digital yang Digunakan } & Mobile-Banking & 75 & $75 \%$ \\
\hline & & Internet-Banking & 25 & $25 \%$ \\
\hline
\end{tabular}

Sumber: Data diolah SPSS v25.00

Pada tabel diatas, jenis kelamin responden hampir berimbang yaitu berjenis kelamin lakilaki ada 48 orang (48\%), sedangkan perempuan ada 52 orang (52\%). Mayoritas berstatus belum menikah sebanyak $73 \%$, berusia antara $20-25$ tahun sebanyak $84 \%$ dengan pendidikan didominasi sarjana (53\%). Dilihat dari karakteristik pekerjaan mayoritas responden sudah bekerja (64\%), dan semua menggunakan fasilitas digital banking bank syariah dengan dominasi penggunaan $\mathrm{m}$-banking sebanyak $75 \%$.

\section{Uji Validitas dan Realibilitas}

Pengujian validitas dengan cara mengambil 30 sampel responden untuk dilakukan konstruksi validitas menggunakan korelasi antara skor item instrument dalam suatu factor dengan skor total. Taraf signifikansi sebesar 5\%, dengan menggunakan rumus df = N-2 maka $\mathrm{df}=30-2=28$ diperoleh nilai R. Bukti pertanyaan dikatakan valid jika nilai $r_{\text {na }}$ positif, serta $r_{h a}>r_{t_{1}}$, begitu sebaliknya.

Tabel 2 Rekapitulasi Uji Validitas Variabel Independen

\begin{tabular}{|c|c|c|c|c|c|c|c|}
\hline \multirow{2}{*}{\multicolumn{4}{|c|}{$\begin{array}{l}\text { Item } r \text { hitung } r \text { tabel } \quad \text { Validitas } \\
\text { Layanan Digital } \\
\mathbf{m} \text {-banking }\end{array}$}} & \multirow{2}{*}{\multicolumn{4}{|c|}{$\begin{array}{l}\text { Item } \mathbf{r} \text { hitung } r \text { tabel Validitas } \\
\text { Layanan Digital i-banking }\end{array}$}} \\
\hline & & & & & & & \\
\hline $\mathrm{q} 1$ & 0,691 & 0,312 & Valid & q9 & 0,687 & 0,312 & Valid \\
\hline $\mathrm{q} 2$ & 0,703 & 0,312 & Valid & $\mathrm{q} 10$ & 0,615 & 0,312 & Valid \\
\hline q3 & 0,716 & 0,312 & Valid & $\mathrm{q} 11$ & 0,647 & 0,312 & Valid \\
\hline $\mathrm{q} 4$ & 0,484 & 0,312 & Valid & $\mathrm{q} 12$ & 0,790 & 0,312 & Valid \\
\hline q5 & 0,753 & 0,312 & Valid & q13 & 0,374 & 0,312 & Valid \\
\hline q6 & 0,679 & 0,312 & Valid & q14 & 0,454 & 0,312 & Valid \\
\hline q7 & 0,628 & 0,312 & Valid & $\mathrm{q} 15$ & 0,604 & 0,312 & Valid \\
\hline q8 & 0,703 & 0,312 & Valid & & & & \\
\hline
\end{tabular}

Sumber: Data diolah SPSS v25.00

Tabel 3 Rekapitulasi Uji Validitas Variabel Dependen

\begin{tabular}{|l|c|c|c|}
\hline Item & r hitung & r tabel & Validitas \\
\hline \multicolumn{2}{|c|}{ Literasi Perbankan Syariah Generasi Milenial } \\
\hline q16 & 0,802 & 0,312 & Valid \\
\hline q17 & 0,636 & 0,312 & Valid \\
\hline q18 & 0,829 & 0,312 & Valid \\
\hline q19 & 0,533 & 0,312 & Valid \\
\hline q20 & 0,785 & 0,312 & Valid \\
\hline q21 & 0,821 & 0,312 & Valid \\
\hline q22 & 0,806 & 0,312 & Valid \\
\hline q23 & 0,331 & 0,312 & Valid \\
\hline q24 & 0,815 & 0,312 & Valid \\
\hline q25 & 0,738 & 0,312 & Valid \\
\hline
\end{tabular}




\begin{tabular}{|l|l|l|l|}
$\mathrm{q} 26$ & 0,735 & 0,312 & Valid \\
\hline q27 & 0,754 & 0,312 & Valid \\
\hline q28 & 0,766 & 0,312 & Valid \\
\hline
\end{tabular}

Sumber: Data diolah SPSS v25.00

Tabel 2 dan 3 diatas menunjukkan bahwa nilai $r$ hitung dari seluruh butir pertanyaan pada variabel penelitian lebih besar dari nilai $r$ tabel ( $r$ hitung $>r$ tabel). Dengan demikian dapat dikatakan bahwa seluruh butir pertanyaan pada variabel penelitian adalah valid.

Selanjutnya untuk mengetahui tingkat reliabilitas menggunakan kriteria nilai Cronbach Alpha. Nilai Cronbach Alpha antara 0,80 sampai dengan 1 dikategorikan reliabilitas baik. Namun Cronbach Alpha kurang dari 0,60 dikategorikan kurang baik, dan sebaliknya. Berdasarkan pada uji reliabilitas, diketahui hasil pengujian reliabilitas sebagai berikut:

Tabel 4 Hasil Uji Reliabilitas

\begin{tabular}{|l|c|c|c|}
\hline \multicolumn{1}{|c|}{ Variabel } & $\begin{array}{c}\text { Nilai Cronbach } \\
\text { Alpha }\end{array}$ & $\begin{array}{c}\text { Ketentuan Nilai } \\
\text { Cronbach Alpha }\end{array}$ & Status \\
\hline $\begin{array}{l}\text { Layanan Keuangan Digital } \\
\text { m-Banking }\end{array}$ & 0,753 & 0,600 & Reliabel \\
\hline $\begin{array}{l}\text { Layanan Keuangan Digital i- } \\
\text { Banking }\end{array}$ & 0,682 & 0,600 & Reliabel \\
\hline Literasi Keuangan Syariah & 0,765 & 0,600 & Reliabel \\
\hline
\end{tabular}

Sumber: Data diolah SPSS v25.00

Tabel 4 menunjukkan hasil uji reliabilitas semua variabel independen dan dependen diatas angka 0,600. Sehingga dapat disimpulkan bahwa seluruh item pertanyaan telah memenuhi syarat reliabilitas atau dengan kata lain bahwa tingkat reliabilitas angket ini reliabel sebagai penelitian.

\section{Uji Asumsi Klasik}

\section{a. Uji Normalitas}

Tujuan uji Normalitas adalah untuk mengetahui apakah dalam sebuah model regresi variabel dependen, variabel independen atau keduanya mempunyai distribusi normal atau tidak. Dasar pengambilan keputusan dalam uji Normalitas yakni: jika nilai signifikansi lebih besar dari 0,05 maka data tersebut berdistribusi normal. Sebaliknya, jika nilai signifikansi lebih kecil dari 0,05 maka data tersebut tidak berdistribusi normal. Berdasarkan output dari tabel 5 di bawah, diketahui bahwa nilai signifikansi sebesar 0,089 lebih besar dari 0,05, sehingga dapat disimpulkan bahwa data yang di uji berdistribusi normal.

\section{Tabel 5 Uji Normalitas}

\begin{tabular}{|c|c|c|}
\hline & Unstandardized Residual \\
\hline \multicolumn{2}{|l|}{$\mathrm{N}$} & 100 \\
\hline \multirow{2}{*}{ Normal Parameters ${ }^{\mathrm{a}, \mathrm{b}}$} & Mean & 0,0000000 \\
\hline & Std. Deviation & 13,18294874 \\
\hline \multirow{3}{*}{ Most Extreme Differences } & Absolute & 0,099 \\
\hline & Positive & 0,052 \\
\hline & Negative & $-0,099$ \\
\hline \multicolumn{2}{|l|}{ Kolmogorov-Smirnov Z } & 0,099 \\
\hline \multicolumn{2}{|l|}{ Asymp. Sig. (2-tailed) } & 0,089 \\
\hline
\end{tabular}




\section{b. Uji Heteroskedastisitas}

Pembambilan keputusan menggunakan metode uji Glejser dilihat dari nilai signifikansi antara variabel independen dengan absolut residual. Jika nilai signifikansi variabel lebih dari 0,05 maka tidak terjadi masalah heteroskedastisitas.

Tabel 6 Uji Gletjer

\begin{tabular}{|c|c|c|c|c|c|c|}
\hline & & Unstandardize & Coefficients & $\begin{array}{c}\text { Standardized } \\
\text { Coefficients }\end{array}$ & $\mathrm{t}$ & Sig. \\
\hline Mo & & $\mathrm{B}$ & Std. Error & Beta & & \\
\hline & (Constant) & 12,389 & 3,084 & & 4,017 & 0,000 \\
\hline 1 & Mobile Banking & 0,112 & 0,106 & 0,193 & 1,054 & 0,294 \\
\hline & Internet Banking & $-0,162$ & 0,128 & $-0,232$ & $-1,267$ & 0,208 \\
\hline
\end{tabular}

Dari tabel diatas dapat diketahui bahwa nilai signifikansi variabel independen mobile banking sebesar 0,294 dan variabel internet banking sebesar 0,208 lebih besar dari 0,05. Dengan demikian dapat disimpulkan bahwa tidak terjadi masalah heteroskedatisitas pada model regresi ini.

\section{c. Uji Autokorelasi}

Pengambilan keputusan dalam uji run test adalah dengan melihat nilai Asymp. Sig. (2tailed), jika nilai signifikan lebih dari 0,05 maka tidak terjadi autokorelasi, atau sebaliknya.

Tabel 7 Uji Runs Test

\begin{tabular}{|l|r|}
\hline & Unstandardized Residual \\
\hline Test Value $^{\mathrm{a}}$ & -0.34221 \\
\hline Cases $<$ Test Value & 47 \\
\hline Cases >= Test Value & 53 \\
\hline Total Cases & 100 \\
\hline Number of Runs & 42 \\
\hline$Z$ & $-1,779$ \\
\hline Asymp. Sig. (2-tailed) & 0,075 \\
\hline a. Median \\
\hline Sumber: Data diolah SPSS v25.00
\end{tabular}

Dari tabel tersebut terlihat bahwa nilai signifikan 0,075, artinya hasil run test lebih besar dari 0,05 . Dengan demikian, data yang dipergunakan cukup random sehingga tidak terdapat masalah autokorelasi pada data yang diuji.

\section{Uji Regresi Linier Berganda}

Analisis regresi linier berganda ini digunakan untuk mengetahui pengaruh variabel $\mathrm{m}$ banking dan i-banking terhadap literasi keuangan syariah generasi milenial. Adapun hasil dari analisis regresi berganda sebagai berikut:

Tabel 8 Ringkasan Hasil Ujii Regresi Berganda

\begin{tabular}{|l|r|r|r|}
\hline Variabel & Koefisien Regresi & t hitung & \multicolumn{1}{c|}{ sign. } \\
\hline Konstanta & $-1,516$ & $-0,322$ & 0,748 \\
\hline m-banking & 0,930 & 5,748 & 0,0000 \\
\hline i-banking & 0,928 & 4,764 & 0,0000 \\
\hline F-statistik & 164,410 & & 0,0000 \\
\hline R-square & 0,775 & & \\
\hline
\end{tabular}

Sumber: Data diolah SPSS v25.00 


\section{a. Uji Simultan (Uji F-Statistik)}

Pengujian F-statistik ditujukan untuk pengujian secara serentak atau bersama-sama pada setiap variabel independen terhadap variabel dependen. Pengujian ini melihat apakah kedua variabel $\mathrm{X}$ yang terdiri dari m-banking (X1), i-banking (X2), memiliki pengaruh secara bersama-sama terhadap variabel $(\mathrm{Y})$ yaitu literasi keuangan generasi milenial. Berdasarkan table 8, diketahui bahwa nilai sig F hitung lebih kecil dari titik kritis $5 \%(0,000<0,05)$, maka dapat disimpulkan bahwa variabel m-banking dan i-banking secara bersama-sama memiliki pengaruh terhadap variabel literasi keuangan syariah generasi milenial.

Kemudian, untuk nilai koefisien determinasi ( $R$-Square) sebesar 0,775 yang mengandung pengertian bahwa pengaruh variabel bebas ( $m$-banking dan $i$-banking) terhadap variabel terikat (literasi keuangan syariah generasi milenial) adalah sebesar $77,5 \%$, sedangkan sisanya $(22,5 \%)$ dipengaruhi oleh variabel selain dari penelitian ini.

\section{b. Uji Parsial (Uji t-statistik)}

Uji parsial bertujuan untuk mengetahui ada tidaknya pengaruh variabel layanan digital perbankan syariah terhadap literasi generasi milenial. Dengan melihat nilai signifikansi masing-masing variabel, maka dapat diketahui apakah hipotesis diterima atau ditolak. Tabel 8 menunjukkan hasil regresi berganda bahwa masing-masing variabel independen signifikan mempengaruhi variabel dependen yang dilihat dari nilai signifansi $0,000<0,05$.

Persamaan regresi yang terbentuk adalah $Y=-1,516+0,930 X_{1}+0,928 X_{2}$. Konstanta sebesar -1,516 menyatakan bahwa jika tidak ada nilai layanan digital bank syariah maka tingkat literasi keuangan syariah generasi milenial minus sebesar -1,516. Koefisien regresi $m$ banking sebesar 0,930 menyatakan bahwa setiap penambahan 1 nilai penggunaan m-banking mampu menambah literasi keuangan syariah generasi milenial sebesar 0,930. Begitu pula koefisien $i$-banking sebesar 0,928 .

\section{c. Uji Mann-Whitney}

Teknik analisis data menggunakan analisis komparasional, yaitu yaitu analisis data yang bersifat hubungan perbedaan antara variabel yang satu dengan yang lainnya atau antara fakta yang satu dengan yang lainnya. Uji Mann-Whitney digunakan untuk mencari perbedaan literasi generasi milenial yang sudah bekerja dan mahasiswa. Hasil pengujian dapat dilihat pada tabel di bawah ini:

Tabel 9 Hasil Uji Mann-Whitney Rank

\begin{tabular}{|l|l|l|c|c|}
\hline & Pekerjaan & N & Mean Rank & Sum of Ranks \\
\hline $\begin{array}{l}\text { Literasi Keuangan Syariah } \\
\text { Generasi Milenial }\end{array}$ & Mahasiswa & 36 & 27,13 & 976,50 \\
\hline \multicolumn{5}{|c|}{ Test Statistics } \\
\hline \multicolumn{4}{|c|}{ Literasi Keuangan Syariah Generasi Milenial } \\
\hline $\begin{array}{l}\text { Literasi Keuangan Syariah } \\
\text { Generasi Milenial }\end{array}$ & Mann-Whitney U & Wilcoxon W & Z & $\begin{array}{l}\text { Asymp. Sig. (2- } \\
\text { tailed) }\end{array}$ \\
\hline Nilai & 310,500 & 976,500 & $-6,045$ & 0,0000 \\
\hline
\end{tabular}

Sumber: Data diolah SPSS v25.00

Dari output diatas bisa diliat mean pekerja lebih besar dari pelajar/mahasiswa yaitu $63,65>27,13$ yang menggambarkan bahwa $63,65 \%$ pekerja memiliki literasi keuangan syariah yang lebih baik. Dari hasil di atas pada baris Asymp. Sig (2-tailed) terlihat bahwa nilai probabilitas $0,000<0,05$ dan Ho ditolak. Hasil uji menggambarkan bahwa ada perbedaan 
tingkat literasi antara pekerja dengan mahasiswa. Dengan kata lain mayoritas dari pekerja telah memiliki literasi keuangan syariah yang baik.

\section{Pembahasan Hasil Uji Hipotesis}

Pada penelitian ini literasi keuangan syariah generasi milenial signifikan dipengaruhi oleh variabel $m$-Banking dan $i$-Banking. Dari hasil uji regresi dapat dikatakan bahwa ketika bank syariah tidak melakukan layanan digital, maka literasi keuangan syariah generasi milenial menjadi rendah atau berkurang. Hal ini karena generasi milenial cenderung lebih menyukai transaksi secara non-tunai, dan melek teknologi ${ }^{25}$. Sehingga layanan digital berupa $m$-Banking dan $i$-Banking efektif meningkatkan literasi keuangan syariah generasi milenial. Analisis lebih lanjut mengenai pengaruh dari masing-masing variabel penelitian dijelaskan sebagai berikut:

\section{a. Pengaruh $\boldsymbol{m}$-banking Terhadap Literasi Keuangan Syariah Generasi Milenial}

Perkembangan teknologi yang cepat dan mengarah ke layanan berbasis digital dengan mengurangi tenaga manusia, lebih mengutamakan sistem yang lebih canggih dan serba otomatis sangat sesuai dengan karakteristik generasi milenial. Perkembangan teknologi ini juga berdampak pada dunia perbankan, saat ini bank berlomba-lomba menciptakan layanan digital untuk memberikan kemudahan bagi nasabah bank dalam melakukan transaksi. Adapun bentuk layanan digital yang diciptakan bank diantaranya adalah mobile-banking ${ }^{26}$. Mobile-banking merupakan salah satu layanan bank melalui teknologi handphone $e^{27}$, dalam layanan $m$-banking ini terdapat berbagai macam fasilitas transaksi finansial seperti transfer dana antar rekening dan antar bank, pembayaran telepon, listrik, air, BPJS, zakat, pembelian pulsa handphone, pembayaran tagihan kartu kredit, dan lain sebagainya. Selain transaksi finansial, m-banking juga menyediakan fasilitas transaksi non finansial untuk cek saldo tabungan, mutasi rekening, dan mengubah private identity number $(\mathrm{PIN})^{28}$ yang sangat membantu nasabahnya.

Generasi milenial sangat dekat dengan dunia digital. Dunia digital mampu memberikan ruang kepada mereka dalam mengakses, memperoleh, dan men-share (membagikan) segala macam informasi yang mereka peroleh dari internet. Generasi milenial juga disebut sebagai masyarakat digital. Selain itu generasi ini juga disebut generasi praktis, hal ini karena generasi milenial cenderung menyukai hal-hal yang serba instan, cepat dan mudah ${ }^{29}$. Layanan $m$ banking sangat disukai generasi ini, mereka bisa menggunakannya kapanpun dan dimanapun selagi masih tersambung jaringan internet ${ }^{30}$.

Hasil penelitian ini menunjukkan adanya pengaruh yang signifikan antara layanan digital bank syariah menggunakan m-banking dengan literasi keuangan syariah generasi milenial.

${ }^{25}$ Ira Eka Pratiwi, Fachrudin Fiqri Affandy, and Yuyun Rosalina, "Determinan Penggunaan Digital Banking Pada Generasi Milenial Muslim : Pendekatan Technology f Acceptance Model ( Studi Kasus Di Kota Jayapura , Indonesia )," Jurnal Imliah Ekonomi Islam 6, no. 03 (2020): 478-487.

${ }^{26}$ Admaja Dwi Herlambang and Arimbi Dewanti, "Minat Nasabah Dalam Menggunakan Layanan Mobile Banking," Jurnal Ilmiah Teknologi Informasi Asia 12, no. 1 (2018): 48.

${ }^{27}$ Miftahuddin Miftahuddin and Decky Hendarsyah, "Analisis Perbandingan Fasilitas Aplikasi Mobile Banking Bank Syariah Mandiri KCP. Bengkalis Dengan Bank Mandiri KC. Bengkalis,” IQTISHADUNA: Jurnal $\begin{array}{lllllll}\text { Ilmiah Ekonomi } & \text { Kita } & 8, & \text { no. } & 1 & \text { (2019): } & 16-32 \text {, }\end{array}$ https://ejournal.stiesyariahbengkalis.ac.id/index.php/iqtishaduna/article/view/149.

${ }^{28}$ Dede Sri Sudaryanti, Nana Sahroni, and Ane Kurniawati, "Analisa Pengaruh Mobile Banking Terhadap Kinerja Perusahaan Sektor Perbankan Yang Tercatat Di Bursa Efek,” Jurnal Ekonomi Manajemen 4, no. 2 (2018): 96-107.

${ }^{29}$ Sapta Sari, "Literasi Media Pada Generasi Milenial Di Era Digital," Profesional: Jurnal Komunikasi dan Administrasi Publik 6, no. 2 (2019): 30-42.

${ }^{30}$ Adi Pratama et al., "Faktor-Faktor Yang Mempengaruhi Niat Dalam Menggunakan Mobile-Banking," Jurnal Akun Nabelo: Jurnal Akuntansi Netral, Akuntabel, Objektif 2, no. 1 (2019): 123-128. 
Artinya, dengan adanya layanan digital m-banking bank syariah, dapat meningkatkan pemahaman generasi milenial tentang keuangan syariah. Generasi milenial bisa mendapatkan pengetahuan yang ingin diperoleh mengenai fiture perbankan yang diberikan melalui fasilitas $m$-banking. Layanan yang diberikan tersebut mampu memberikan efisiensi waktu dan biaya ${ }^{31}$.

Perkembangan saat ini, transaksi perbankan tidak lagi harus dilakukan secara manual dengan datang ke bank, sekarang cukup dengan aplikasi m-banking dari smart-phone nasabah sudah cukup. Selain menghemat waktu dan biaya, m-banking memiliki tujuan agar nasabah bank juga mengikuti perkembangan zaman yang sudah modern dengan media elektronik. Sehingga dengan mengikuti perkembangan ini, generasi milenial menjadi melek teknologi dan memiliki literasi keuangan syariah yang baik ${ }^{32}$.

\section{b. Pengaruh i-banking Terhadap Literasi Keuangan Syariah Generasi Milenial}

Saat ini, dunia perbankan mengikuti perkembangan teknologi dengan memanfaatkan internet, dengan mediasi internet perbankan memberikan layanan digital internet banking ( $i$ banking ${ }^{33}$. Internet banking (i-banking) adalah layanan jasa bank untuk nasabah dalam mendapatkan informasi, melakukan komunikasi, serta transaksi perbankan lewat jaringan internet. Layanan digital $i$-banking bisa diakses melalui handphone, leptop, dan komputer. Ibanking dapat menggantikan transaksi yang biasa dilakukan di ATM (Anjungan Tunai Mandiri), kecuali tarik tunai ${ }^{34}$. Layanan digital $i$-Banking sangat cocok bagi generasi milenial yang lebih menyukai transaksi secara non tunai (online), tanpa ribet, mudah, cepat, efektif dilakukan dimana saja dan kapan saja selama 24 jam dan tanpa mengenal hari libur. Sehingga, tidak lagi harus mengantri di depan teller saat ingin melakukan transaksi transfer, dan transaksi pembayaran lainnya ${ }^{35}$.

Sama halnya dengan m-banking, tujuan layanan digital $i$-banking bank syariah selain memudahkan pelayanan transaksi kepada nasabah bank juga bermaksud untuk meningkatkan pemahaman generasi milenial tentang keuangan syariah. Hal ini dikarenakan tidak semua nasabah bank syariah paham tentang keuangan syariah. Mengingat kebiasaan generasi milenial yang serba digital, penelitian ini menemukan bahwa fasilitas i-banking berpengaruh positif signifikan terhadap literasi keuangan syariah generasi milenial.

Adanya layanan digital $i$-banking bank syariah akan membuat generasi milenial mencari tahu informasi dan mempelajari fitur layanan serta produk-produk yang ada di layanan digital $i$-banking bank syariah. Dengan demikian literasi atau pemahaman mereka tentang keuangan syariah akan semakin baik. Sehingga dapat diambil kesimpulan bahwa dengan adanya layanan digital $i$-Banking bank syariah, dapat meningkatkan pemahaman generasi milenial tentang keuangan syariah.

${ }^{31}$ Ira Anisa Purawinangun and Maulana Yusuf, "Gerakan Literasi Generasi Milenial Melalui Media Sosial," Lingua Rima: Jurnal Pendidikan Bahasa dan Sastra Indonesia 9, no. 1 (2020): 67.

32 Abi Fadlan and Rizki Yudhi Dewantara, "Pengaruh Persepsi Kemudahan Dan Persepsi Kegunaan Terhadap Penggunaan Mobile Banking (Studi Pada Mahasiswa Pengguna Mobile Banking Universitas Brawijaya)," Jurnal Administrasi Bisnis (JAB) 62, $\quad$ no. $1 \quad$ (2018): 82-89, http://administrasibisnis.studentjournal.ub.ac.id/index.php/jab/article/viewFile/2652/3045.

${ }^{33}$ Muhammad Yakup, Abdul Gani, and Emil Salim Siregar, "Pengaturan Hukum Terhadap Layanan Internet Banking Dalam Transaksi Perbankan,” Jurnal Pionir LPPM Universitas Asahan 6, no. 1 (2020): 31-37.

${ }^{34}$ Pratiwi, Affandy, and Rosalina, "Determinan Penggunaan Digital Banking Pada Generasi Milenial Muslim : Pendekatan Technology f Acceptance Model ( Studi Kasus Di Kota Jayapura , Indonesia ).”

${ }^{35}$ Pratama et al., "Faktor-Faktor Yang Mempengaruhi Niat Dalam Menggunakan Mobile-Banking." 


\section{c. Perbedaan Literasi Keuangan Syariah Generasi Milenial antara Mahasiswa dengan Pekerja}

Berdasarkan hasil Uji Mann-Whitney Rank menggambarkan bahwa ada perbedaan tingkat literasi antara pekerja dengan mahasiswa. Pekerja sendiri dimaknai sebagai orang yang melakukan pekerjaan (bekerja) dengan tujuan untuk mendapatkan gaji atau upah dan imbalan dalam bentuk lain ${ }^{36}$. Sedangkan mahasiswa diartikan sebagai siswa yang sedang menimba ilmu di perguruan tinggi. Berdasarkan dari hasil Uji Mann-Whitney Rank bahwa mayoritas pekerja memiliki literasi keuangan syariah yang baik dibanding mahasiswa, hal ini karena pekerja dan mahasiswa memiliki perbedaan hasil yang diperoleh, pekerja bekerja untuk memperoleh gaji dan mahasiswa belajar untuk memperoleh ilmu. Jika dimaknai secara kasat mata, mahasiswa yang berilmu tentu memiliki pengetahuan tentang keuangan syariah lebih baik dibanding pekerja, namun pada kenyataannya pekerja yang memperoleh gaji justru lebih baik pengetahuan tentang keuangan syariahnya. Hal ini dikarenakan mahasiswa hanya sebatas mempelajari teori dan akan mudah lupa karena termakan waktu. Sedangkan pekerja sebagai pengguna fasilitas digital bank syariah lebih sering bersinggungan dengan fasilitas tersebut. Selain itu, pekerja yang memiliki gaji tentu akan mencari informasi terkait keuangan syariah lebih detail mengenai informasi yang berkaitan dengan manfaat, fitur, serta layanan digital bank syariah seperti $m$-Banking dan $i$-Banking. Pencarian informasi ini dilakukan agar dapat memutuskan bank syariah mana yang tepat untuk menyimpan gaji, bertransaksi daring, berinvestasi, maupun mengelola keuangannya.

\section{Simpulan}

Hasil penelitian menunjukkan bahwa m-banking dan $i$-banking berpengaruh signifikan dan positif terhadap literasi bank syariah generasi milenial di Kudus. Nilai R-square sebesar 0,775 yang berarti kontribusi pengaruh yang diberikan oleh layanan m-banking dan i-banking terhadap literasi keuangan syariah generasi milenial di Kudus sebesar 77,5\%, sedangkan sisanya sebesar 22,5\% dipengaruhi oleh variabel lain. Melalui layanan digital bank syariah seperti m-banking dan $i$-banking, generasi milenial dapat memperoleh literasi/pemahaman yang lebih baik mengenai industri perbankan syariah. Fitur, manfaat dan risiko, hak dan kewajiban terkait produk dan jasa bank syariah menjadi lebih mudah digunakan dan dipahami oleh generasi milenial.

Selanjutnya perkembangan digitalisasi perbankan syariah saat ini diharapkan mampu mendorong peningkatan pemanfaatan produk dan jasa keuangan yang sesuai dengan kebutuhan generasi milenial muslim pada khususnya dan masyarakat luas pada umumnya. Hal ini akan memotivasi perbankan syariah untuk menigkatkan kemudahan dalam memberikan pelayanan perbankan syariah melalui fasilitas digital banking sesuai dengan kebutuhan masyarakat yang selalu berkembang.

\section{Daftar Pustaka}

Amalia, Hanny, N Eva Fauziah, and Ifa Hanifia. "Effectiveness and Efficiency of Digital Financial Services System in Employee of DPU Daarut Tauhiid." In Posiding Keuangan Dan Perbankan Syariah, 442-446, 2017.

Astutik, Yuni. “Ada 2 Masalah Di Balik Literasi Keuangan Digital RI.” Last modified 2020. https://www.cnbcindonesia.com/news/20200824170208-4-181599/ada-2-masalah-di-

\footnotetext{
${ }^{36}$ Maimun, Hukum Ketenagakerjaan Suatu Pengantar (Jakarta: PT. Pradnya Paramita, 2013).
} 
balik-literasi-keuangan-digital-ri. diakses tanggal 25 Desember 2020

Churry. "Literasi Keuangan Digital Meningkat Di Tengah Pandemi." Last modified 2020. https://www.itworks.id/33720/literasi-keuangan-digital-meningkat-di-tengahpandemi.html. diakses tanggal 25 Desember 2020

Dz., Abdus Salam. "Inklusi Keuangan Perbankan Syariah Berbasis Digital-Banking: Optimalisasi Dan Tantangan." Al-Amwal : Jurnal Ekonomi dan Perbankan Syari'ah 10, no. 1 (2018): 63.

Fadlan, Abi, and Rizki Yudhi Dewantara. "Pengaruh Persepsi Kemudahan Dan Persepsi Kegunaan Terhadap Penggunaan Mobile Banking (Studi Pada Mahasiswa Pengguna Mobile Banking Universitas Brawijaya)." Jurnal Administrasi Bisnis (JAB) 62, no. 1 (2018): http://administrasibisnis.studentjournal.ub.ac.id/index.php/jab/article/viewFile/2652/ 3045.

Fatimah, Siti Bunga, and Achsania Hendratmi. "Digitalisasi Pada Bank Mandiri Syariah Di Tengah Persaingan Dan Perubahan Teknologi.” Jurnal Ekonomi Syariah Teori dan Terapan 7, no. 4 (2020): 795.

Herdiana, Dikdik. "Digital Financial Services (Layanan Keuangan Digital): Peluang Dan Kemungkinan Penerapannya Di Program KOTAKU." Advisory Consultant National Slum Upgrading Program (2014): 1-20.

Herlambang, Admaja Dwi, and Arimbi Dewanti. "Minat Nasabah Dalam Menggunakan Layanan Mobile Banking." Jurnal Ilmiah Teknologi Informasi Asia 12, no. 1 (2018): 48.

Junaidi. "Persepsi Masyarakat Untuk Memilih Dan Tidak Memilih Bank Syariah (Studi Kota Palopo)." Fokus Bisnis : Media Pengkajian Manajemen dan Akuntansi 14, no. 2 (2015): 1-13. https://www.researchgate.net/publication/339711561\%0APeran.

Krishna, Ayu, Maya Sari, and Rofi Rofaida. Analisis Tingkat Literasi Keuangan Di Kalangan Mahasiswa Dan Faktor-Faktor Yang Mempengaruhinya, 2011. Literasi Keuangan, Faktor Demografis, Mahasiswa.

Laily, Nujmatul. "Pengaruh Literasi Keuangan Terhadap Perilaku Mahasiswa Dalam Mengelola Keuangan." Journal of Accounting and Business Education 1, no. 4 (2016).

Maimun. Hukum Ketenagakerjaan Suatu Pengantar. Jakarta: PT. Pradnya Paramita, 2013.

Margaretha, Farah, and Reza Arief Pambudhi. "Tingkat Literasi Keuangan Pada Mahasiswa S-1 Fakultas Ekonomi.” JMK 17, no. 1 (2015): 76-85.

Miftahuddin, Miftahuddin, and Decky Hendarsyah. "Analisis Perbandingan Fasilitas Aplikasi Mobile Banking Bank Syariah Mandiri KCP. Bengkalis Dengan Bank Mandiri KC. Bengkalis." IQTISHADUNA: Jurnal Ilmiah Ekonomi Kita 8, no. 1 (2019): 16-32. https://ejournal.stiesyariahbengkalis.ac.id/index.php/iqtishaduna/article/view/149.

Nasir. Metode Penelitian. Jakarta: Ghalia, 2003.

Nugroho, Anton Priyo, and Wuri Suhasti. "Peran Literasi Keuangan Syariah Terhadap Minat 
Menggunakan Pembayaran Non Tunai : Perluasan Teori Technology Acceptance Model Peran Literasi Keuangan Syariah Terhadap Minat Menggunakan Pembayaran Non Tunai : Perluasan Teori Technology Acceptance Model." ResearchGate, no. October (2020). https://www.researchgate.net/publication/339711561\%0APeran.

Nurfalah, Irfan, and Aam Slamet Rusydiana. "Digitalisasi Keuangan Syariah Menuju Keuangan Inklusif: Kerangka Maqashid Syariah." Ekspansi: Jurnal Ekonomi, Keuangan, Perbankan dan Akuntansi 11, no. 1 (2019): 55.

OJK. Survei Nasional Literasi Dan Inklusi Keuangan 2019. Survey Report, 2019. www.ojk.go.id.

Otoritas Jasa Keuangan. Strategi Nasional Literasi Keuangan Indonesia. Otoritas Jasa Keuangan, 2017.

Pratama, Adi, Fadli Moh. Saleh, Femilia Zahra, and Nadhira Afdhalia. "Faktor-Faktor Yang Mempengaruhi Niat Dalam Menggunakan Mobile-Banking." Jurnal Akun Nabelo: Jurnal Akuntansi Netral, Akuntabel, Objektif 2, no. 1 (2019): 123-128.

Pratiwi, Ira Eka, Fachrudin Fiqri Affandy, and Yuyun Rosalina. "Determinan Penggunaan Digital Banking Pada Generasi Milenial Muslim: Pendekatan Technology f Acceptance Model ( Studi Kasus Di Kota Jayapura , Indonesia ).” Jurnal Imliah Ekonomi Islam 6, no. 03 (2020): 478-487.

Purawinangun, Ira Anisa, and Maulana Yusuf. "Gerakan Literasi Generasi Milenial Melalui Media Sosial.” Lingua Rima: Jurnal Pendidikan Bahasa dan Sastra Indonesia 9, no. 1 (2020): 67.

Sari, Sapta. "Literasi Media Pada Generasi Milenial Di Era Digital." Profesional: Jurnal Komunikasi dan Administrasi Publik 6, no. 2 (2019): 30-42.

Seftarita, Chenny, and Uliya Azra. “Analisis Peluang Penggunaan Layanan Keuangan Digital (Lkd) Pada Masyarakat Kabupaten Aceh Besar Provinsi Aceh.” Jurnal Ekombis III, no. 1 (2017): 1-16. http://180.250.41.45/ekombis/article/view/385.

Sobaya, Soya, and Junaidi Safitri. "Pengaruh Literasi Keuangan Dan Lingkungan Sosial Terhadap Perencanaan Keuangan Pegawai Di Universitas Islam Indonesia." ResearchGate, no. June (2016).

Sudaryanti, Dede Sri, Nana Sahroni, and Ane Kurniawati. "Analisa Pengaruh Mobile Banking Terhadap Kinerja Perusahaan Sektor Perbankan Yang Tercatat Di Bursa Efek." Jurnal Ekonomi Manajemen 4, no. 2 (2018): 96-107.

Sugiyono. Metode Penelitian Kuantitatif. Bandung: CV. Alfabet, 2017.

Sumadi, S. "Menakar Dampak Fenomena Pandemi Covid-19 Terhadap Perbankan Syariah." Jurnal Hukum Ekonomi Syariah, no. 1 (2020): 145.

Susilawaty, Lilis, and Nicola Nicola. "Pengaruh Layanan Perbankan Digital Pada Kepuasan Nasabah Perbankan.” Jurnal Manajemen Maranatha 19, no. 2 (2020): 179-190.

Tahliani, H. "Tantangan Perbankan Syariah Dalam Menghadapi Pandemi Covid-19." Madani Syariah 3, no. 2 (2020): 92-113. https://stai-binamadani.ejournal.id/Madanisyariah/article/view/205. 
Vebiana, Vera. "Perbankan Digital, Pengalaman Pelanggan , Dan Kinerja Keuangan Bank Syariah." 9th Industrial Research Workshop and National Seminar (2018): 747-751. file:///C:/Users/win7/Downloads/1145-Article Text-2220-1-10-20180830 (1).pdf.

Welly, Kardinal, and Ratna Juwita. "Analisis Pengaruh Literasi Keuangan Terhadap Keputusan Investasi Di STIE Multi Data Palembang." Jurnal Ilmu Ekonomi (2018): $1-16$.

Wise, Sean. "The Impact of Financial Literacy on New Venture Survival." International Journal of Business and Management 8, no. 23 (2013): 30-39.

Yakup, Muhammad, Abdul Gani, and Emil Salim Siregar. "Pengaturan Hukum Terhadap Layanan Internet Banking Dalam Transaksi Perbankan." Jurnal Pionir LPPM Universitas Asahan 6, no. 1 (2020): 31-37. 